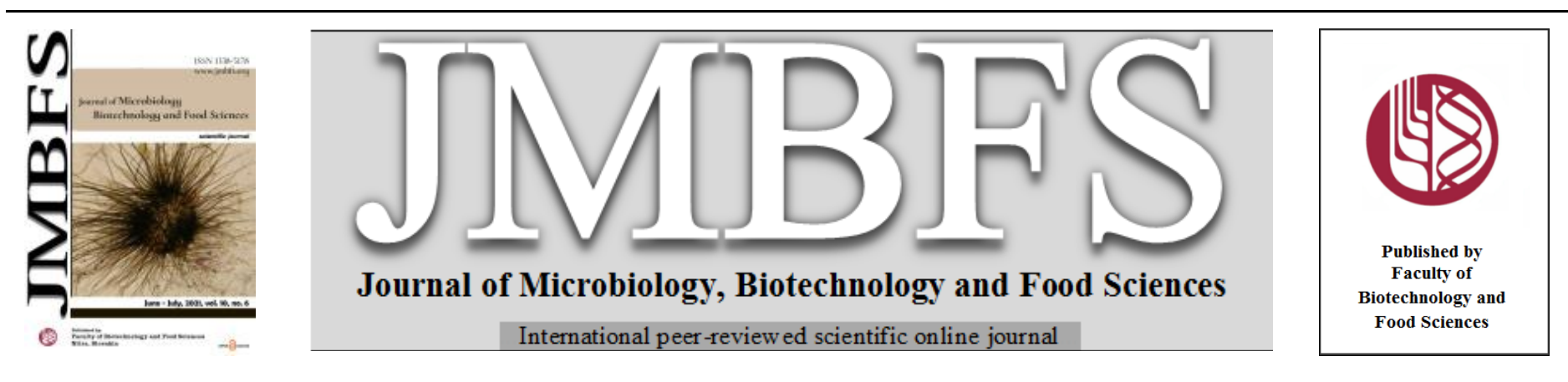

\title{
PROPOLIS: ANTIMICROBIAL ACTIVITY AND CHEMICAL COMPOSITION ANALYSIS
}

\author{
Hana Bouzahouane ${ }^{1,2, *}$, Adel Ayari, ${ }^{1,3}$, Ines Guehria ${ }^{1,4}$ and Ouafa Riah ${ }^{1}$ \\ $\operatorname{Address}(e s):$ \\ ${ }^{1}$ Department of Biology, Faculty of natural and life sciences, Mohamed Cherif Messaadia University, Souk-Ahras, 41000, Algeria. \\ ${ }^{2}$ Laboratory of Environmental Biosurveillance, Department of Biology, Faculty of Sciences, Badji Mokhtar University, BP 12, El Hadjar, Annaba 23000, Algeria \\ ${ }^{3}$ Laboratory of Aquatic and Terrestrial Ecosystems, Mohamed Cherif Messaadia University, Souk-Ahras, 41000, Algeria. \\ ${ }^{4}$ University of Tunis El Manar, Faculty of Sciences of Tunis, LR01ES05 Biochemistry and Biotechnology, 2092 , Tunis 1.
}

*Corresponding author: hana_microbiologie@yahoo.fr

https://doi.org/10.15414/jmbfs.3211

\section{ARTICLE INFO}

Received 2. 6. 2020

Revised 23. 12. 2020

Accepted 30. 12. 2020

Published 1. 6. 2021

Regular article

open 2 access

\begin{abstract}
Over the last few years, propolis has been the object of many studies conducted around the world, and its biological properties and chemical composition have been widely investigated. The present study focuses on the evaluation of the antimicrobial activity as well as an examination of the chemical composition of two samples of propolis from Eastern Algeria coming from the commune of El Mechrouha and Ouled Driss in the wilaya of Souk-Ahras. The two samples are tested for their antimicrobial power by undertaking the agar diffusion technique on eight pathogenic microbial strains (six bacterial strains and two fungal strains) which are: Escherichia coli, Klebsiella pneumonia, Pseudomonas aeruginosa, Staphylococcus aureus, Streptococcus agalactiae, Streptococcus thoraltensis, , , Candida famata and Aspergillus niger. The results obtained clearly show the impact of propolis on the microbial susceptibility of Grampositive bacteria (S. agalactiae and S. aureus), as well as on fungal species (C. famata and A. niger). The analysis of the chemical composition of the ethanolic extracts of the two propolis by UV-visible absorption spectrometry and thin layer chromatography showed that Algerian propolis is wealthy in phenolic compounds, and high performance liquid chromatography allowed the identification of four polyphenols (Gallic acid, Caffeic acid, Quercetin and Catechin). These outcomes permitted a first assessment of the two propolis which present comparable components in their chemical compositions.
\end{abstract}

Keywords: Antibacterial effect, Antifungal effect, Bacteria, Flavonoids, Fungus, Polyphenols

\section{INTRODUCTION}

Apitherapy is one of the practices in natural care, based on products of the hive such as: honey, royal jelly, propolis ... etc. Propolis is a resinous product gathered by honey bees from tree buds (Dimov et al., 1991; Amoros et al., 1992). Its main constituents are beeswax, resin and volatile matter. Mostly, the biological activity of propolis is ascribed to these plant-extracted substances. It has been appeared to have pharmacological properties for example antibacterial, antifungal, antiviral, anti-inflammatory, antioxidant and immunostimulant (Silici et al., 2007).

Successful medical experiments with propolis have prompted expanded interest in its chemical composition and origin. For quality control purposes, chemical tests should be joined with biological tests, particularly antimicrobial tests. The antimicrobial activity of propolis has been broadly studied, affirming its antibacterial, antifungal, antiviral and antiprotozoal character (Vardar-Ünlü $\boldsymbol{e}$ al., 2008). Krol et al. (1993) detailed that propolis extracts potentiate certain antibiotic effects attributing the antimicrobial activity of propolis for the most part to flavonoids or to a synergy between certain phenolic components (Vijay, 2013). The main bioactive components coming from North American and European sources are flavanones, flavones and flavanols. Apart from flavonoids, aldehydes, alcohols, aromatic and aliphatic acids, amino acids, chalcones, steroids, sugars and terpenoids have additionally been detected in propolis (Silici et al., 2007). Numerous experiments have been carried out on the chemical constitution of propolis, the results of which have shown that this composition depends on the botanical source of this resin. Propolis of temperate areas is essentially composed of phenolics such as flavonoids and cinnamic acid byproducts. Besides these compounds, tropical propolis are rich in diterpenes, lignans and some other prenylated compounds (Segueni, 2011). Algeria, despite its geographical position which differs from the other areas mentioned above, is likely to supply different propolis, especially from a chemical viewpoint. The antimicrobial activity and chemical properties of propolis are essential parameters for its characterization (Silici et al., 2007). All these data led us to study the biological properties of two propolis from Eastern Algeria. A comparative study based on antimicrobial activity was carried out: the antibacterial and antifungal effects of propolis extracts were tested on clinically pathogenic microorganisms including bacteria, fungus and yeast. An analysis of the chemical composition of the propolis extracts in order to discover their main components. Our work focused on polyphenols and more particularly flavonoids, which are essential elements of several biological activities of propolis, like the antimicrobial one. The identification and structure determination of these components is carried out by visible UV spectrometry, as well as other chromatographic techniques.

\section{MATERIAL AND METHODS}

\section{Material used}

The propolis samples used in this study were given by beekeepers from two distinct regions of Eastern Algeria. The first sample came from El Mechrouha and the second from the commune of Ouled Driss, wilaya of Souk-Ahras, Algeria. The propolis of El Mechrouha is brown-black in colour while the propolis of Ouled Driss is brown in colour which extends towards yellow. The strains on which the study was carried out (Escherichia coli, Klebsiella pneumonia, Pseudomonas aeruginosa, Staphylococcus aureus, Streptococcus agalactiae, Streptococcus thoraltensis, Candida famata and Aspergillus niger) were isolated from the pathological samples, tested by automatic machines for their identification and their resistance to standard antibiotics.

Evaluation of the antimicrobial activity of propolis

\section{Extraction}

Based on the extraction protocol described by Park and Ikegaki (1998), propolis is subjected to a maceration extraction consisting of a $60 \%, 70 \%, 80 \%$ and $95 \%$ $(\mathrm{V} / \mathrm{V})$ ethanol/water mixture. Propolis is added to ten volumes of solvent of its weight (for $1 \mathrm{~g}$ of propolis, we add $10 \mathrm{ml}$ of solvent). This mixture is left for one week at room temperature with periodic stirring, to obtain a solution containing propolis. After maceration this mixture is warmed in a hot-water bath at $70^{\circ} \mathrm{C}$ for 30 minutes. The preparation is ready and must be filtered through a filter paper. 
The extract obtained is called Ethanolic Propolis Extract (EPE: EPE1 Ethanolic Propolis Extract of El Mechrouha and EPE2 Ethanolic Propolis Extract of Ouled Driss). This extract is subjected to the study of the chemical profile and the determination of the antibiogram (Segueni, 2011).

\section{Antibiogram by agar diffusion method (disc method)}

The NCCLS technique (National Commite for Clinical Laboratory Standars) is used in this study.

The antibiogram is based on the observation of strain growth in the presence of a concentration gradient of an antimicrobial substance, obtained by diffusion from the discs into a Mueller Hinton (MH) agar medium (CA-SFM, 2010). For Streptococci, fresh blood MH was used.

- Cut Whatman No. 3 paper into $6 \mathrm{~mm}$ diameter discs.

- Place the discs in glass vials for sterilisation in an autoclave for 20 minutes at $120^{\circ} \mathrm{C}$.

- Using a Pasteur pipette or the sterile platinum handle, remove a microbial colony.

- Prepare the inoculum of each microbial strain and inoculate it onto the $\mathrm{MH}$ medium.

- Place each paper disc with sterile forceps on the MH medium and immediately impregnate it with $50 \mu \mathrm{L}$ with ethanolic extract of propolis $60 \%, 70 \%, 80 \%$ and $95 \%$.

- Incubate the dishes at $35^{\circ} \mathrm{C}$ within $30 \mathrm{~min}$ after preparation and leave for 16 to $18 \mathrm{~h}$

Accurately measure the diameters of the inhibition zones using a Caliper.

\section{Extraction and purification of the chemical components of propolis}

Flavonoic products are sought by UV-visible absorption and separated by thin layer chromatography (TLC) and high performance liquid chromatography (H.P.L.C).

\section{UV-visible absorption}

The concept is based on the absorption of light by the chemical species, the apparatus includes a white light source, a dispersive system that allows us to select the wavelength of the radiation and a detector system for measuring the light intensity of the monochromatic radiation that passes through the solution The spectrophotometer compares the incident and transmitted light intensities by means of an electronic circuit that indicates the absorbance (Zeghad, 2009).

The UV-visible absorption spectra of EPE 1 and 2 are performed according to the method used by Park and Ikegaki (1998) (Segueni, 2011).

- $25 \mu \mathrm{l}$ of EPE is diluted in $30 \mathrm{ml}$ of $95 \%$ ethanol.

- Mix well and leave at room temperature for one hour

We used a JENWAY UV 6705 spectrophotometer to record absorbances at wavelengths ranging from 200 to $600 \mathrm{~nm}$. Measurements were carried out in quartz vats with an optical pathway of $1 \mathrm{~cm}$ (Kitouni, 2007).

\section{Thin layer chromatography $(T L C)$}

This technique is based on the partition of the different constituents of an extract according to their migration force in the mobile phase which is generally a mixture of solvents adapted to the type of separation sought and their affinity for the stationary phase which can be a polyamide gel or a silica gel. It allows us to have the fingerprints of the polyphenolic flavonoic content of the extract (Bobbitt et al., 1968)

Preparation of the stationary phase: TLC was performed on pre-poured silica gel plates.

Preparation of the mobile phase: The mobile phase consists of a mixture of organic solvents. For this purpose, different solvent systems have been tested to define those that give the best separations with different proportions as follows:

1. $95 \%$ ethanol / distilled water (V/V: 55/45),

2. n-butanol/acetic acid/distilled water (BAW) (V/V/V: 4/1/5),

3. Petroleum Ether/Ethyl Acetate (V/V: 7/3) (Zeghad, 2009).

- The deposition is done with disposable glass capillary tubes in a perpendicular and linear way.

Plate development: Each plate is deposited in a vertical or slightly inclined position in the vat previously saturated by the vapors of the appropriate solven system, the sample to be studied will be more or less entrained by progressive capillarity of the mobile phase towards the top of the plate (Zeghad, 2009).

Revelation: If the constituents are colored, they will be directly visible on the plate, otherwise they can be revealed by UV light, which allows the UV absorbing substances between $254 \mathrm{~nm}$ and $365 \mathrm{~nm}$ to be highlighted as spots.
Identification of flavonoids: The behavior of a particular molecule in a given system is expressed by its fluorescence under UV light and by its Retention factor (Rf).

$\mathrm{Rf}=$ distance between the origin and the spot of the product /distance from the origin to the solvent front

\section{Structure-Rf}

The migration distance of the substances depends mainly on their polarity as well as on their structures for example:

The increase of $(\mathrm{OH})$ causes a decrease in $\mathrm{Rf}$, Methylation of $(\mathrm{OH})$ groups and Acetylation leads to an increase in Rf values, whereas Glycosylation causes a decrease in $\mathrm{Rf}$ values mainly due to the introduction of new $(\mathrm{OH})$ groups.

Polyhydroxyflavones have low Rf values (0.00-0.25).

Oligohydroxyflavones and oligomethoxyflavones have $\mathrm{Rf}$ values between $(0.3$ $0.5)$

Flavanones, flavonols, methoxyflavones have the highest $\mathrm{Rf}$ values $(0.5-0.75)$ (Zeghad, 2009)

\section{Structure-fluorescence}

Ultraviolet light examination is the most widely used method for the determination of the structure of flavonoids (Zeghad, 2009).

\section{High Performance Liquid Chromatography (H.P.L.C.) Analysis}

HPLC is a very powerful separation technique, it is widely used in many industries such as food, chemical and pharmaceutical industries, cosmetics, etc.. It is a physico-chemical method based on the differences in interactions between the molecules to be separated and the mobile and stationary phases. Beforehand the solutes are put in solution in the mobile phase (solvent). After its injection, this mixture passes under high pressure through the column (stainless steel tube) which contains the stationary phase (Nollet and Toldra, 2012). The analyses were performed using an HPLC-C18 chromatograph, furnished with the following elements:

- A column (with a length of $125 \mathrm{~mm}$ and an internal diameter of $4.6 \mathrm{~mm}$ ) containing the apolar stationary phase (reverse phase), the latter consisting of silica chemically modified by grafting residues (C-18), these reverse phase columns allow the separation of polar compounds, soluble in water or in hydroalcoholic mixtures;

- A pumping system, Pump: Varian 9010, to move the mobile phase at high pressure (several tens of bars);

- One injector: Varian 9100, to introduce the sample into the high-pressure system ;

- A monochrome detector: Varian 9065;

- Computer software to visualize the signals recorded by the detector.

The working conditions are as follows:

- Flow rate: $0.5 \mathrm{ml} / \mathrm{min}$

- Working pressure: 100-150 bar;

- Injection volume: $30 \mu \mathrm{l}$;

- Wavelength: $254 \mathrm{~nm}$;

- Sample concentration: $1-5 \mathrm{mg} / \mathrm{ml}$;

- Analysis time: $15 \mathrm{~min}$;

The mobile phase is of constant composition, it is composed of a methanol-water mixture (60: $40 \mathrm{~V} / \mathrm{V})$ (Kuntić et al., 2007).

\section{RESULTS AND DISCUSSION}

\section{Results of the evaluation of the antimicrobial activity of propolis}

We studied the antimicrobial potency in vitro of the ethanol extracts of the two propolis by the disc diffusion method on a solid agar medium, Mueller Hinton (MH).

Discs impregnated with $50 \mu \mathrm{l}$ of EPE1 and EPE2 with the 4 different concentrations of ethanol at $60 \%, 70 \%, 80 \%$ and $95 \%$ were tested by the NCCLS method.

The antimicrobial activity of the extracts was estimated regarding the diameter of the inhibition zone around the discs containing the extracts to be tested against pathogenic microorganisms which are: S. aureus, S. agalactiae, S. thoraltensis $K$. pneumonia, E. coli, P. aeruginosa, C. famata and A. niger.

Ethanol has been tested as a solvent, the results show that it is suitable and has no effect on the normal growth of microbial strains.

Results of the diameters of the inhibition zones show that $80 \%$ EPE gives the largest diameters for all strains.

According to Table 1, the highest zones of inhibition were observed against $A$ niger $(20 \mathrm{~mm}$ and $18 \mathrm{~mm})$, S. aureus $(16 \mathrm{~mm}$ and $15 \mathrm{~mm})$ and $S$. agalactiae $(14$ $\mathrm{mm}$ and $12 \mathrm{~mm}$ ), treated with EPE1 and EPE2 at 80\%. Propolis from Ouled Driss (EPE2) scored a diameter of $10.5 \mathrm{~mm}$ against the yeast $C$. famata greater than that obtained with propolis from El Mechrouha $(8.25 \mathrm{~mm})$ 
Table 1 Diameters of inhibition zones (mm) of EPE1 and EPE2 for the strains studied

\begin{tabular}{|c|c|c|c|c|c|c|c|c|}
\hline \multirow[b]{2}{*}{ Strains } & \multicolumn{4}{|c|}{ EPE (1) } & \multicolumn{4}{|c|}{ EPE (2) } \\
\hline & $60 \%$ & $70 \%$ & $80 \%$ & $95 \%$ & $60 \%$ & $70 \%$ & $80 \%$ & $95 \%$ \\
\hline Staphylococcus aureus & 13 & 13,5 & 16 & 14,25 & 14 & 14,25 & 15 & 13,5 \\
\hline Streptococcus agalactiae & 11,5 & 12 & 14 & 8,5 & 10,5 & 11,5 & 12 & 8,5 \\
\hline Streptococcus thoraltensis & - & - & - & - & - & - & - & - \\
\hline Escherichia coli & - & - & - & - & - & - & - & - \\
\hline Klebsiella pneumoniae & - & - & - & - & - & - & - & - \\
\hline Pseudomonas aeruginosa & - & - & - & - & - & - & - & - \\
\hline Candida famata & $<6$ & 7 & 8,25 & 7,25 & 7 & 8 & 10,5 & 9 \\
\hline Aspergillus niger & 14 & 17 & 20 & 18 & 12 & 15,5 & 18 & 16 \\
\hline
\end{tabular}

Legend: (-) - Absence of the inhibition zone, EPE (1) - Ethanolic Propolis Extract of El Mechrouha, EPE (2) - Ethanolic Propolis Extract from Ouled Driss

Results of the extraction and purification of the active components

\section{$U V$-visible absorption spectrum}

The results of the UV-visible spectral analysis of the two propolis show a single absorption peak (Figure 1), which corresponds to band I (between 300 and 350 $\mathrm{nm}$ ) of flavonoids. We assume that these peaks correspond to Flavones, Flavonols and Flavanones.
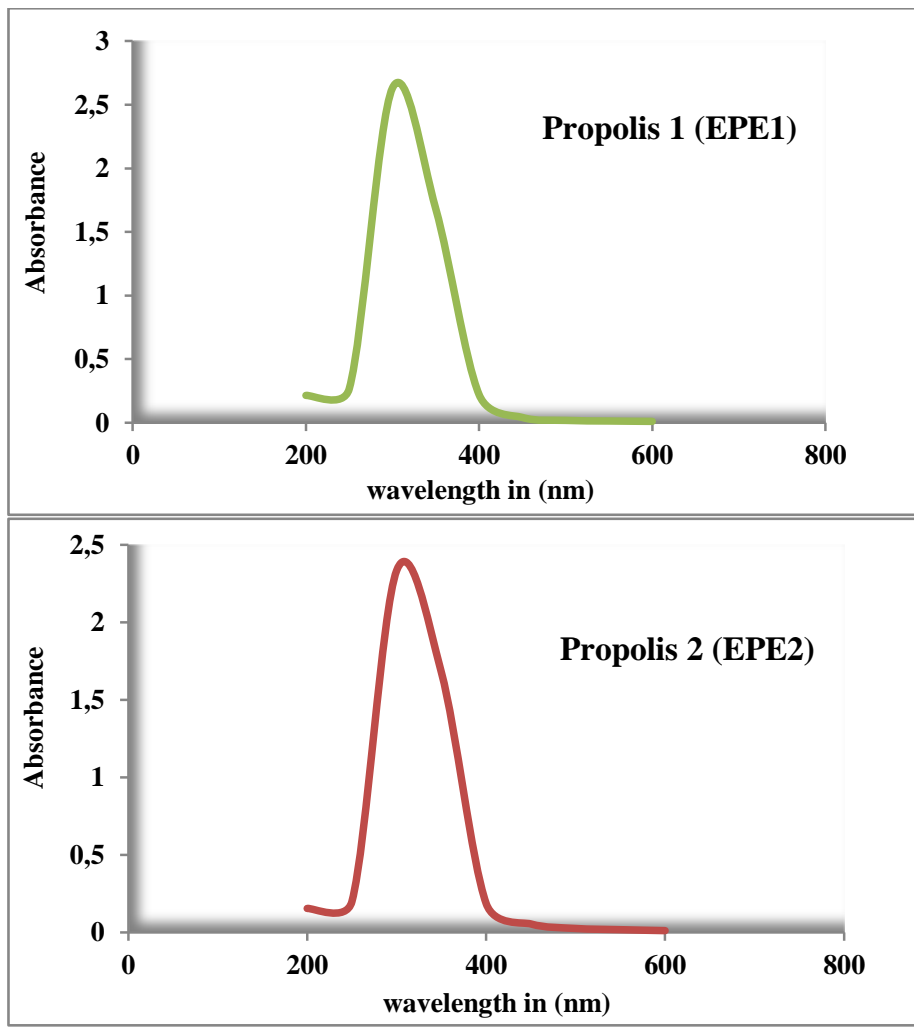

Figure 1 UV-visible absorption spectrum of propolis from El Mechrouha (EPE1) and propolis from Ouled Driss (EPE2)

\section{Thin layer chromatography (TLC)}

Three solvent systems were used, the resulting chromatograms have a series of spots (Figure 2). The chromatograms show that the number of spots as well as the colours obtained vary according to the solvent system used and the wavelength of the UV lamp (254-365 $\mathrm{nm})$.

The identification of the components depends on the comparison of $\mathrm{Rf}$ and the colour observed under UV light (Tab 2 and Tab 3). These tables include the Rf of the different spots that appeared with the different solvent systems used as well as the colour revealed under UV light at two different wavelengths (254 and $365 \mathrm{~nm}$ ). Using these solvent systems and at a wavelength of $254 \mathrm{~nm}$, we were able to highlight: five spots with the solvent system (95\% ethanol/distilled water), two spots with the solvent system (BAW) and seven spots with the system (petroleum ether and ethyl acetate), with colours that vary between brown-black, brown and violet; and an almost similar Rf for the two EPEs. On the other hand, the wavelength of $365 \mathrm{~nm}$ revealed: five spots with the first solvent system, four spots with the second and thirteen spots with the third solvent system, which show colour variability (blue, violet and yellow fluorescence); with almost similar Rf for the two EPEs.

We noticed that the third solvent system (petroleum ether/ethyl acetate) gave the highest number of spots, revealed distinct spots and showed a considerable richness of flavonic substances in the two EPEs analysed, unlike the other two solvent systems which revealed a streak, which explains a poor separation of the components.

Table 2 Chromatographic pattern of the El Mechrouha EPE

\begin{tabular}{|c|c|c|c|}
\hline The extracts & Eluent system & $\begin{array}{c}\text { UV spot color at } \\
254 \mathrm{~nm}\end{array}$ & $\mathbf{R f}$ \\
\hline \multirow{38}{*}{ EPE 1 at $80 \%$} & \multirow{5}{*}{$\begin{array}{c}95 \% \text { ethanol/distilled } \\
\text { water }(55 / 45)\end{array}$} & Violet & 0,35 \\
\hline & & Brown & 0,58 \\
\hline & & Dark violet & 0,68 \\
\hline & & Dark violet & 0,75 \\
\hline & & Dark violet & 0,90 \\
\hline & \multirow[t]{2}{*}{ BAW (4/1/5) } & Light violet & 0,80 \\
\hline & & Dark violet & 0,92 \\
\hline & \multirow{7}{*}{$\begin{array}{l}\text { Petroleum ether and ethyl } \\
\text { acetate }(7 / 3)\end{array}$} & Violet & 0,18 \\
\hline & & Dark violet & 0,34 \\
\hline & & Dark brown & 0,47 \\
\hline & & Light brown & 0,52 \\
\hline & & Light brown & 0,60 \\
\hline & & Light brown & 0,72 \\
\hline & & Light brown & 0,84 \\
\hline & Eluent system & UV spot color at & Rf \\
\hline & \multicolumn{2}{|c|}{$365 \mathrm{~nm}$} & \\
\hline & \multirow{5}{*}{$\begin{array}{l}95 \% \text { ethanol/distilled } \\
\text { water }(55 / 45)\end{array}$} & Orange & 0,32 \\
\hline & & Yellow & 0,50 \\
\hline & & Violet & 0,67 \\
\hline & & Green-yellow & 0,71 \\
\hline & & Brown & 0,8 \\
\hline & \multirow{4}{*}{ BAW (4/1/5) } & Light violet & 0,48 \\
\hline & & yellow-green & 0,7 \\
\hline & & $\begin{array}{l}\text { Bright yellow- } \\
\text { green }\end{array}$ & 0,81 \\
\hline & & Violet & 0,92 \\
\hline & \multirow{13}{*}{$\begin{array}{l}\text { Petroleum ether and ethyl } \\
\text { acetate }(7 / 3)\end{array}$} & Light blue & 0,04 \\
\hline & & Blue & 0,08 \\
\hline & & Violet & 0,11 \\
\hline & & Orange & 0,20 \\
\hline & & Light violet & 0,27 \\
\hline & & Light blue & 0,32 \\
\hline & & Yellow & 0,37 \\
\hline & & Light violet & 0,41 \\
\hline & & Dark violet & 0,47 \\
\hline & & Dull yellow & 0,51 \\
\hline & & Light violet & 0,62 \\
\hline & & Dark violet & 0,75 \\
\hline & & Orange & 0,84 \\
\hline
\end{tabular}




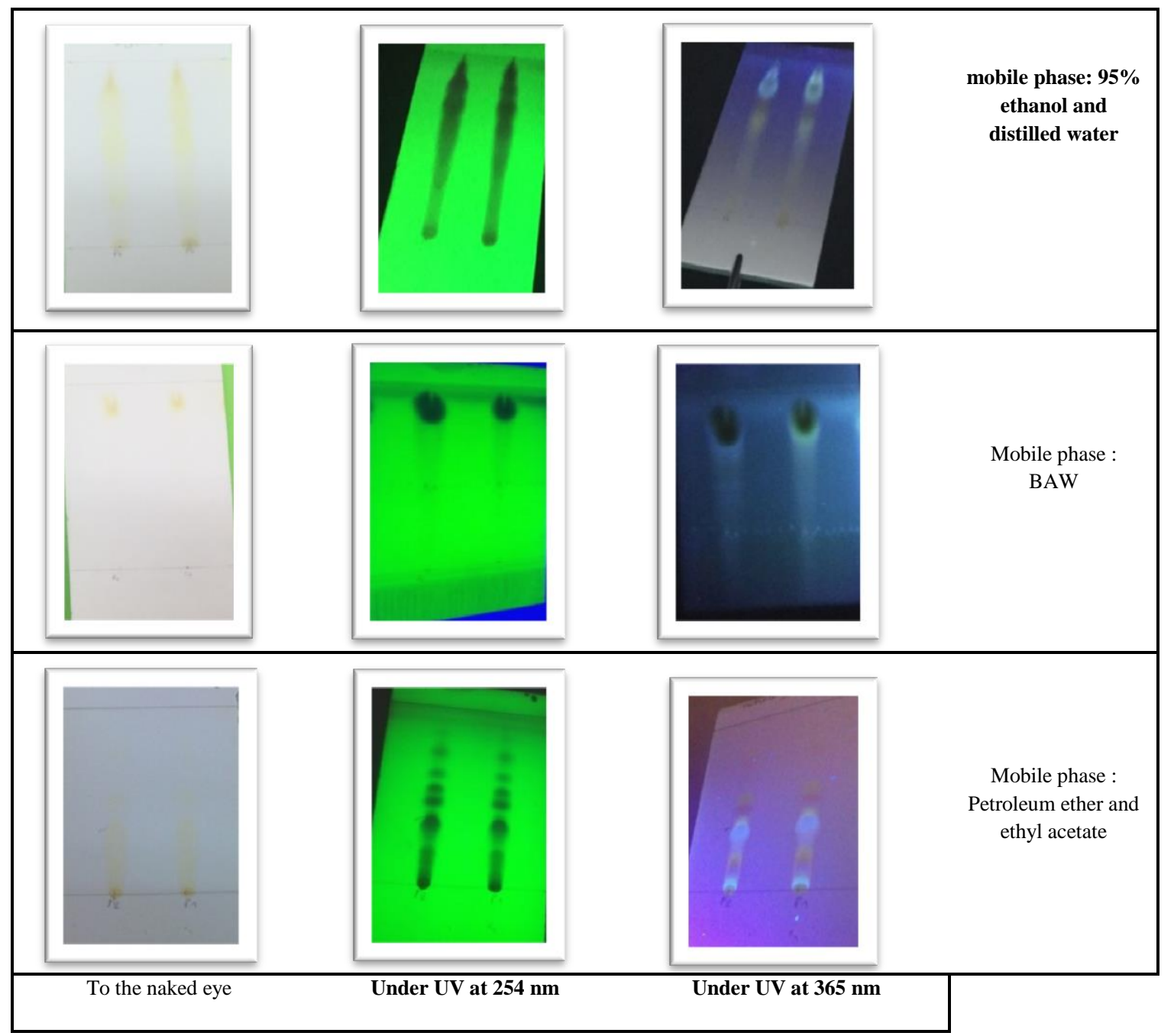

Figure 2 Chromatogram of the two EPEs by different mobile phases

Table 3 Chromatographic pattern of the Ouled Driss EPE

\begin{tabular}{|c|c|c|c|}
\hline The extracts & Eluent system & $\begin{array}{c}\text { UV spot color at } \\
254 \mathrm{~nm}\end{array}$ & $\mathbf{R f}$ \\
\hline & \multirow{5}{*}{$\begin{array}{l}95 \% \\
\text { ethanol/distilled } \\
\text { water }(55 / 45)\end{array}$} & Light violet & 0,22 \\
\hline & & Brown & 0,32 \\
\hline & & Brun-noir & 0,57 \\
\hline & & Brown & 0,74 \\
\hline & & Brown & 0,87 \\
\hline & \multirow{2}{*}{ BAW (4/1/5) } & Light violet & 0,80 \\
\hline & & Dark violet & 0,92 \\
\hline & \multirow{7}{*}{$\begin{array}{l}\text { Petroleum ether and } \\
\text { ethyl acetate }(7 / 3)\end{array}$} & Violet & 0,20 \\
\hline & & Dark violet & 0,35 \\
\hline & & Brun-noir & 0,45 \\
\hline & & Brown & 0,52 \\
\hline & & Brown & 0,65 \\
\hline & & Brown & 0,74 \\
\hline \multirow{13}{*}{ EPE2 at $80 \%$} & & Light brown & 0,84 \\
\hline & Eluent system & $\begin{array}{c}\text { UV spot color at } \\
365 \mathrm{~nm}\end{array}$ & $\mathbf{R f}$ \\
\hline & \multirow{6}{*}{$\begin{array}{l}95 \% \\
\text { ethanol/distilled } \\
\text { water }(55 / 45)\end{array}$} & Yellow & 0,25 \\
\hline & & Orange & 0,60 \\
\hline & & Violet & 0,71 \\
\hline & & Green & 0,82 \\
\hline & & Brown & 0,88 \\
\hline & & Light violet & 0,92 \\
\hline & \multirow{5}{*}{ BAW (4/1/5) } & Violet & 0,55 \\
\hline & & Violet & 0,61 \\
\hline & & Violet & 0,80 \\
\hline & & Brown & 0,87 \\
\hline & & Light blue & 0,04 \\
\hline
\end{tabular}

\begin{tabular}{lll}
\hline \multirow{2}{*}{$\begin{array}{l}\text { Petroleum ether and } \\
\text { ethyl acetate (7/3) }\end{array}$} & Blue & 0,08 \\
\cline { 2 - 3 } & Violet & 0,11 \\
\cline { 2 - 3 } & Orange & 0,20 \\
\cline { 2 - 3 } & Light violet & 0,27 \\
\cline { 2 - 3 } & Light blue & 0,32 \\
\cline { 2 - 3 } & Yellow & 0,37 \\
\cline { 2 - 3 } & Light violet & 0,41 \\
\hline Dark violet & 0,47 \\
\hline Yellow-orange & 0,51 \\
\hline Light violet & 0,62 \\
\hline
\end{tabular}

\section{High Performance Liquid Chromatography (H.P.L.C.) Analysis}

The results of the HPLC-C18 analysis of the active extract P1 are shown in Figure 3. As can be observed (depending on the number of peaks on the chromatograms), the extract is richer in chemical substances and this confirms the results obtained by TLC. Six pure phenolic compounds (Gallic Acid, Tannic Acid, Caffeic Acid, Catechin, Rutin, and Quercetin) were used in the H.P.L.C. analysis as controls. Their chromatograms and retention times (Rt) are shown in Figure 3. H.P.L.C. identified four polyphenols in the ethanolic extract among the six studied: Gallic Acid, Caffeic Acid, Quercetin and Catechin. 

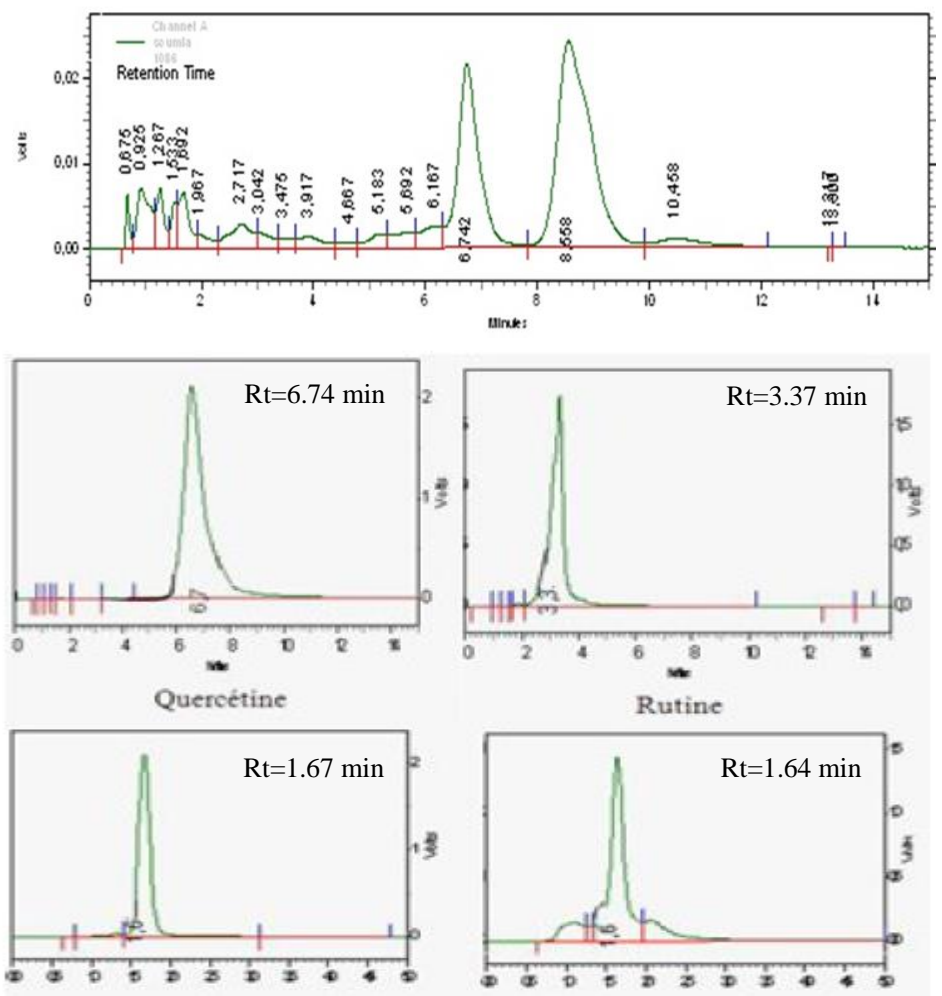

Acide gallique

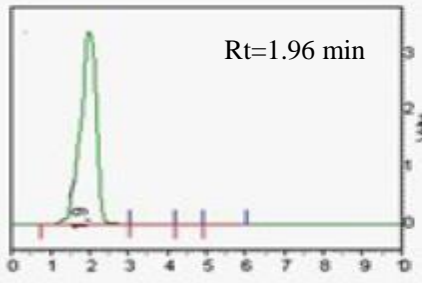

Acide cafeìque

Acide tannique

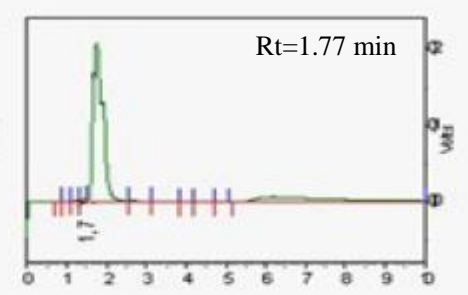

Catéchine

Figue 3 H.P.L.C. chromatograms of EPE1 and controls with the retention time (Rt) of the different polyphenolic controls.

\section{Choice of solvent}

We used ethanol (at different percentages) as a solvent for the study of antimicrobial activity for the following reasons:

- Propolis cannot be utilized directly as a crude material because it is difficult to establish simple fractionation to get compounds because of its complex structure. The usual methodology is the utilization of a solvent, which should eliminate impurities and retain the desired components. Since the composition of propolis depends mainly on the vegetation from which it was gathered, but also on the methods utilized for extraction, the solvent used for the extraction of bioactive compounds should be carefully chosen (Fokt et al., 2010).

- A current and common procedure is to extract the alcohol-soluble fraction (Ghisalberti, 1979).

- Ethanol is the most common choice of solvent, as it allows the extraction of different classes of chemical components such as Polyphenols and Flavonols, and studies concerning the assessment of the bioactivity of propolis have been carried out using mainly ethanol extracts of propolis (Fokt et al., 2010).

- Ethanol is used in the composition of several therapeutic preparations (Brehon et al., 2000). It evaporates easily and solubilizes the active components of propolis (Krell, 1996). Its effectiveness in the study of antimicrobial activity is confirmed by Drago et al. (2000) and Park et al. (2002) (Segueni, 2011).

\section{Antimicrobial activity of propolis}

The inhibition zones of a good antimicrobial agent differ from one author to another, according to Pereira et al. (2006) the inhibition zone must be equal or greater than $10 \mathrm{~mm}$, for Vieira et al. (2001) it is $13 \mathrm{~mm}$ and according to Kim et al. (2006) it is greater than $6 \mathrm{~mm}$. In all cases the components of propolis extracts could be good antimicrobial agents. The use of EPE at different percentages of ethanol by the disc method shows that the diameter of the inhibition zone of propolis depends on its solubility in the solvent and consequently on its diffusion in the medium, this phenomenon is reported in the work carried out by Tabera $\boldsymbol{e t}$ al. (2000). The diameters obtained indicate that the active compounds of propolis are more soluble in $80 \%$ ethanol. These components are probably flavonoids. They would be involved in the antimicrobial activity of propolis (Segueni, 2011) The results obtained are consistent with those of Bonvehì and Gutiérrez (2012), who observed inhibition zones of 10 to $16 \mathrm{~mm}$ for $S$. aureus while considering that they obtained good antibacterial activity of their propolis and reported medium sized inhibition zones against Streptococcus pyogenes ( 4 to $12 \mathrm{~mm}$ ), as well as against $C$. albicans (4 to $10 \mathrm{~mm}$ ) and no activity for $E$. coli. Kumar et al (2008) studied the antimicrobial activity of propolis gathered from Gujarat using the agar diffusion method against Bacillus subtilis, E. coli, P. aeruginosa, $S$ aureus, C. albicans and A. niger. Using Ethanol Extracts from the sample of this propolis, they demonstrated high antibacterial activity towards Gram positive bacteria, i.e. B. subtilis, however less effect against Gram negative bacteria $(E$. coli and $P$. aeruginosa). C. albicans indicated zones of moderate inhibition while it showed no activity against $A$. niger (Vijay 2013).

The work of Gonsales $\boldsymbol{e t}$ al. (2006) revealed that Brazilian propolis samples yielded inhibition zone diameters against $S$. aureus between $8-13 \mathrm{~mm}$, which are comparable to the results of Prytzyk et al. (2003) for Bulgarian propolis. The inhibition zones of Argentine propolis are less than $10 \mathrm{~mm}$ for $S$. pyogenes and more than $10 \mathrm{~mm}$ for $S$. aureus (Nieva Moreno et al., 1999). Chinese and Japanese propolis produces inhibition zones going from 5.5 to $6.8 \mathrm{~mm}$ with $S$ mutans (Ikeno et al., 1991). Stepanović et al. (2003) found that the propolis inhibition zone in different parts of Serbia was between 18 to $23 \mathrm{~mm}$. Our findings are in the similar range as those revealed in this study, but the literature demonstrates that the susceptibility of microorganisms and differences in the active components of propolis that have antibacterial and antifungal activities are strongly influenced by changes in geographical origins (Bankova et al., 2000). The low susceptibility identified for $E$. coli was consistent with many publications, where it was inferred that this bacterium had a very low sensitivity to the bactericidal activity of propolis (Kujumgiev et al., 1999; Nieva Moreno et al., 1999; Bonvehì and Coll, 2000). The most conceivable explication for the low sensitivity demonstrated by Gram negative bacteria could be attributed to their external membrane which inhibits and/or delays the penetration of propolis at lower concentrations; however this effect is not yet completely clarified. Another possible explanation could be the presence of multi-drug pumps (MDR) which expel amphipathic toxins through the external membrane (Tegos et al. 2002; Bonvehi and Gutierrez, 2012).

According to Boyanova et al. (2005), the antifungal activity could be related to the presence of flavonoids and other phenolic components as for antibacterial activities. Variations in the fungicidal effect of propolis extracts may be credited to differences in the chemical composition and concentration of propolis compounds (Fokt et al., 2010). We suspect that this variation might be associated with the chemical composition of propolis. Bonvehi and Gutiérrez (2012) show that the antioxidant activity of Basque propolis varies with differences in phenolic compounds. Takaisi-Kikuni and Schilcher (1994) reveal by electron microscopy and micro-colorimetric analyses that EPE interferes with the division of $S$. agalactiae by pseudo-multicellular formation, disruption of the cytoplasm, inhibition of protein synthesis, causing bacterial lysis (Fokt et al., 2010). Mirzoeva et al. (1997) report that EPE and some phenolic components affect the bioenergetic state of the membrane by inhibiting the membrane potential, causing enhanced membrane permeability to ions and immobility of B. subtilis. In general, the two EPEs tested inhibit the strains studied and result in diameters that vary depending on the origin of the propolis, the species considered and the percentage of alcohol used.

\section{Extraction and purification of active components}

Flavonoids can be considered as pigments that absorb UV radiation very strongly, consequently UV-Visible spectroscopy represents the principal method for the structural examination of flavonoids. Flavones and flavonols are characterized in majority by two major absorption bands (peaks) in the UVVisible region. Highly oxygenated flavones and flavonols have a tendancy of absorbance towards the more extended wavelengths, resulting in a shift of the spectrum towards the infrared. Glycosylation or methylation of the hydroxyl groups of flavonoids generally results from a hypsochromic shift of band I (Zeghad, 2009).

Comparing our flavonoid assay results by visible UV spectrum to those of Zeghad (2009) our propolis includes the following portions: flavones, flavanols and isofavone.

Segueni (2011) carried out an assay of 4 samples of Eastern Algerian propolis using the ethanol spectrum and she obtained 2 absorbance peaks, one band II between 200 and $250 \mathrm{~nm}$ and the other band I between 300 and $350 \mathrm{~nm}$ which correspond to the flavonoid family.

Our results are in agreement with this work and showed that the 2 propolis samples tested by the ethanol spectrum are rich in flavonoids. According to the results obtained, a blue or violet fluorescence is in favour of a flavone and a flavanone, while a yellow fluorescence is in favour of a flavonol. Nearly close Rf values for the two EPEs can testify to the presence of polyhydroxyflavones, oligohydroxyflavones and methoxyflavones. The two EPEs vary in type (nature 
of the spot) and amount (surface of the spot. This could be due to variations in the origin of the propolis.

We also noted that EPE1 and EPE2 appear to have compounds in common with similar profiles, but with different concentrations depending on the intensity of the tasks obtained. The presence of flavones and flavonols has been observed by Bankova et al. (1982) in different propolis from the tropical region (Segueni, 2011). Segueni (2011) obtained between 4 and 5 spots using the solvent system 95\% ethanol/distilled water. Propolis is an active product of the hive, it represents a remarkable chemical polymorphism. In the same extract, the biochemical content is very varied. Our results affirmed that the analysed samples had a high antimicrobial effect and flavonoid components are the most appropriate contenders for the assessment of the Algerian propolis quality, because of their diverse biological characteristics and their predominance in the phenolic fraction. Likewise, the higher the content of phenolic and flavonoid compounds, the greater the antimicrobial effect identified in the analysed extracts. H.P.L.C. was not performed for the second propolis sample (EPE2) due to lack of product. The results of the HPLC analysis are in accordance with those of Barrientos $\boldsymbol{e t}$ al. (2013) who worked on the botanical and chemical characterization of Chilean propolis wich their HPLC chromatographic profiles show varying concentrations of myricetin, quercetin, caffeic acid, kaempferol, pinocembrin, apigenin, caffeic acid phenylethyl ester (CAPE) and galangin. On the other hand, the chromatogram obtained by De Aguiar et al. (2013) during their study on antimicrobial activity of Brazilian propolis extracts contains 6 peaks ( $\rho$-coumaric acid, caffeic acid, naringenin, opigenin, CAPE, chrysin and artepillin C). Also Zhang et al. (2015) during their study on comparisons of Ethanol Extracts of Chinese Propolis (EECP) (Poplar Type) and Poplar Gums (EEPG) they obtained chromatograms of 11 compounds in EECP and EEPG: $\rho$-coumaric acid, caffeic acid, ferulic acid, quercetin, resveratrol, apigenin, chrysin, kaempferol, galangin, pinocembrin and CAPE.

\section{CONCLUSION}

Natural substances occupy a large percentage of our daily life and especially in its large therapeutic choice. Indeed, bee propolis constitutes a real chemical bank from which we must take maximum advantage for the well-being of human beings.

Our work, which is devoted to the study of the antimicrobial property of two samples of propolis from Eastern Algeria, has enabled us to observe that the field of beehive products is a vast and fascinating field of scientific research. An antimicrobial evaluation of the two propolis samples shows that it exerts a bactericidal activity specifically against Gram positive bacteria such as Staphylococcus aureus and Streptococcus agalactiae and a remarkable fungicidal effect against Aspergillus niger and moderately interesting against Candida famata which were estimated according to the diameters of the inhibition zones, Gram negative bacteria such as Escherichia coli, Klebsiella pneumonia and Pseudomonas aeruginosa are resistant to this antimicrobial agent (Propolis). This assessment was accompanied by a biochemical study to quantify their levels of phenolic compounds (Flavonoids) by spectrophotometry and thin layer chromatography (TLC). This study allowed us to identify the presence of flavones, flavonones and flavonols in the propolis of Eastern Algeria whose concentrations depend on its origin. High Performance Liquid Chromatography (H.P.L.C.) revealed four polyphenols, namely: Gallic Acid, Caffeic Acid, Quercetin and Catechin. This composition gave us a better classification and standardization of this product for a possible therapeutic use. According to the results we obtained, we can deduce that the propolis of El Mechrouha has a slightly higher antimicrobial activity compared to that of Ouled Driss. It also results that propolis is an attractive, interesting, important and very vas therapeutic product. In fact, propolis is a natural substance which does not need any chemical process, apart from its extraction. By the means of this work, we expect to have made our modest contribution to the valorisation of a precious product of the hive, and to have succeeded in making available to the human being a natural and efficient product.

To develop the extraction and purification of these phenolic compounds so that they can be used in combination with drugs and administered at the clinical level.

Acknowledgement: This study was supported by the Directorate General for Scientific Research and Technological Development (DGRSDT).

\section{REFERENCES}

Amoros, M., Sauvager, F., Girre, L., \& Cormier, M. (1992). In vitro antiviral activity of propolis. Apidologie, 23(3): 240.https://doi.org/10.1051/apido:19920306

Bankova, V. S., Popov, S. S., \& Marekov, N. L. (1982). High-performance liquid chromatographic analysis of flavonoids from propolis. J. Chromatogr. A, 242(1) 135-143.https://doi.org/10.1016/S0021-9673(00)87255-6

Bankova, V. S., De Castro, S. L., \& Marcucci, M. C. (2000). Propolis: recent advances in chemistry and plant origin. Apidologie, 31(1): 3 15.https://doi.org/10.1051/apido:2000102
Barrientos, L., Herrera, C. L., Montenegro, G., Ortega, X., Veloz, J., Alvear, M., Cuevas, A., Saavedra, N., \& Salazar, L. A. (2013). Chemical and botanical characterization of Chilean propolis and biological activity on cariogenic bacteria Streptococcus mutans and Streptococcus sobrinus. Brazilian Journal of Microbiology, $\quad 44(2): \quad$ 577-585.http://dx.doi.org/10.1590/S1517 $\underline{83822013000200038}$

Bobbitt, J. M., Schwarting, A. E., \& Gritter, R. J. (1968). Introduction to chromatography. By Reinhold Book Corporation, Library of congress catalog Card Number, 69-22: 841.https://doi.org/10.1021/ed045pA986.1

Bonvehì, J. S., \& Coll, F. V. (2000). Study on propolis quality from China and

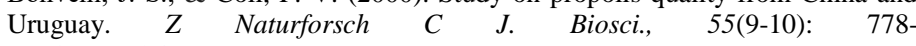
784.https://doi.org/10.1515/znc-2000-9-1017

Bonvehì, J. S., \& Gutiérrez, A. L. (2012). The antimicrobial effects of propolis collected in different regions in the Basque Country (Northern Spain). World J. Microb. Biot., 28: 1351-1358.https://doi.org/10.1007/s11274-011-0932-y

Boyanova, L., Gergova, G., Nikolov, R., Derejian, S., Lazarova, E., Katsarov, N., Mitov, I., \& Krastev, Z. (2005). Activity of Bulgarian propolis against 94 Helicobacter pylori strains in vitro by agar-well diffusion, agar dilution and disc diffusion methods. J. Med. Microbiol., 54: 481483.https://doi.org/10.1099/jmm.0.45880-0

Brehon, S., Giraud, C., \& Certain, A. (2000). L'alcool dans les médicaments Analyses des risques et de l'information des spécialités administrées par voie orale ou injectable. Journal de Pharmacie Clinique, 19(1) : 32-48.

CA-SFM (2011). Comité de l'antibiogramme de la société française de microbiologie. 2010. In: Standardisation de l'antibiogramme à l'échelle nationale (Médecine humaine et vétérinaire). $6^{\text {ème }}$ édition, Document édité avec la collaboration de l'OMS : $192 \mathrm{p}$.

De Aguiar, S. C., Zeoula, L. M., Franco, S. L., Peres, L. P., Arcuri, P. B., \& Forano, E. (2013). Antimicrobial activity of Brazilian propolis extracts agains rumen bacteria in vitro. World J. Microbiol. Biotechnol., 29: 19511959.https://doi.org/10.1007/s11274-013-1361-x

Dimov, V., Ivanovska, N., Manolova, N., Bankova, V., Nikolov, N., \& Popov, S. (1991). Immunomodulatory action of propolis. Influence on anti-infectious protection and macrophage function. Apidologie, 22(2): 155 162.https://doi.org/10.1051/apido:19910208

Drago, L., Mombelli, B., De Vecchi, E., Fassina, M. C., Tocalli, L., \& Gismondo, M. R. (2000). In vitro antimicrobial activity of propolis dry extract. $J$. Chemother., 12(5): 390-395.https://doi.org/10.1179/joc.2000.12.5.390

Fokt, H., Pereira, A., Ferreira, A. M., Cunha, A., \& Aguiar, C. (2010). How do bees prevent hive infections? The antimicrobial properties of propolis. Current Research, Technology and Education Topics in Applied Microbiology and Microbial Biotechnology. A. Méndez-Vilas (Ed.): 481-493.

Ghisalberti, E. L. (1979). Propolis: A review. Bee World, 60(2): 59 84.https://doi.org/10.1080/0005772X.1979.11097738

Gonsales, G. Z., Orsi, R. O., Fernandes Júnior, A., Rodrigues, P., \& Funari, S. R. C. (2006). Antibacterial activity of propolis collected in different regions of Brazil. J. Venom. Anim. Toxins, 12(2): 276-284.https://doi.org/10.1590/S167891992006000200009

Ikeno, K., Ikeno, T., \& Miyazawa, C. (1991). Effects of propolis on dental caries in rats. Caries Res., 25(5): 347-351.https://doi.org/10.1159/000261390

Kim, S., Kubec, R., \& Musah, R. A. (2006). Antibacterial and antifungal activity of sulfur-containing compounds from Petiveria alliacea L. J. Ethnopharmacol., 104(1-2): 188-92.https://doi.org/10.1016/j.jep.2005.08.072

Kitouni, M. (2007). Isolement de bactéries actinomycétales productrices d'antibiotiques à partir d'écosystèmes extrêmes, identification moléculaire des souches actives et caractérisation préliminaire des substances élaborées. Thèse de doctorat, Université Mentouri, Constantine, Algérie : 171 p.

Krell, R. (1996). Value-Added products from beekeeping. FAO Agricultural services, Bulletin $\mathrm{n}^{\circ} 124$.

Krol, W., Scheller, S., Shani, J., Pietsz, G., \& Czuba, Z. (1993). Synergistic effect of ethanolic extract of propolis and antibiotics on the growth of Staphylococcus aureus. Arzneimittelforschung, 43(5): 607-609.

Kujumgiev, A., Tsvetkova, I., Serkedjieva, Y., Bankova, V., Christov, R., \& Popov, S. (1999). Antibacterial, antifungal and antiviral activity of propolis of different geographic origin. J. Ethnopharmacol., 64(3): 235 240.https://doi.org/10.1016/S0378-8741(98)00131-7

Kumar, N., Ahmad, M. K. K., Dang, R., \& Husain, A. (2008). Antioxidant and antimicrobial activity of propolis from Tamil Nadu zone. J. Med. Plant. Res., 2(12): 361-364.

Kuntić, V., Pejić, N., Ivković, B., Vugić, Z., Ilić, K., Mićić, S., \& Vukojević, V. (2007). Isocratic RP-HPLC method for rutin determination in solid oral dosage $\begin{array}{llll}\text { forms. } \quad J . & \text { Pharmaceut. } & \text { Biomed., }\end{array}$ 721.https://doi.org/10.1016/j.jpba.2006.07.019

Mirzoeva, O. K., Grishanin, R. N., \& Calder, P. C. (1997). Antimicrobial action of propolis and some of its components: the effects on growth, membrane potential and motility of bacteria. Microbiol. Res., 152(3): 239246.https://doi.org/10.1016/S0944-5013(97)80034-1

Nieva Moreno, M. I., Isla, M. I., Cudmani, N. G., Vattuone, M. A., \& Sampietro, A. R. (1999). Screening of antibacterial activity of Amaichadel Valle (Tucumán, 
Argentina) propolis. J. Ethnopharmacol., 68(1-3): 97 102.https://doi.org/10.1016/S0378-8741(99)00051-3

Nollet, L. M. L., \& Toldra, F. (2012). Food Analysis by HPLC, Third Edition, CRC Press. Taylor and Francis Group, London, 1078.

Park, Y. K., \& Ikegaki, M. (1998). Preparation of water and ethanolic extracts of propolis and evaluation of the preparations. Biosci. Biotech. Bioch., 62(11): 2230-2232.https://doi.org/10.1271/bbb.62.2230

Park, Y. K., Alencar, S. M., \& Aguiar, L. C. (2002). Estudo da composiçao fenólica de méis e própolis oriundos de mesma colméia. Mensagem Doce, $\mathrm{n}^{\circ} 67$. Pereira, S. L., Cardoso, J. R. V., De Medeiros, P. L., Pereira, R. M. L., De Menezes, V. L. L., Satiro, H. X., \& De Oliveira, E. L. (2006). Antimicrobia activity of Indigofera suffruticosa. Evid-Based Complementary Altern. Med., 3(2): 261-265.https://doi.org/10.1093/ecam/nel010

Prytzyk, E., Dantas, A. P., Salomão, K., Pereira, A. S., Bankova, V. S., De Castro, S. L., \& Netro, F. R. (2003). Flavonoids and trypanocidal activity of Bulgarian propolis. J. Ethnopharmacol., $88(2-3)$ : 189 193.https://doi.org/10.1016/S0378-8741(03)00210-1

Segueni, N. (2011). Contribution à l'étude de la composition chimique et des propriétés biologiques de la propolis. Thèse de doctorat, Université Mentouri de Constantine : $299 \mathrm{p}$.

Silici, S., Ünlü, M., \& Vardar-Ünlü, G. (2007). Antibacterial activity and phytochemical evidence for the plant origin of Turkish propolis from different regions. World J. Microb. Biot., 23 : 1797-1803.https://doi.org/10.1007/s11274007-9430-7

Stepanović, S., Antić, N., Dakić, I., \& Svabić-Vlahović, M. (2003). In vitro antimicrobial activity of propolis and synergism between propolis and antimicrobial drugs. Microbiol. Res., 158(4) : $353-$ 357.https://doi.org/10.1078/0944-5013-00215

Tabera, A., Bedascarrasbure, E., Maldonado, L., Alvarez, A., \& Van Der Horst A. (2000). Actividad antibacteriana de propóleos argentinos enfrentados a Staphylococcus aureus. Congreso Internacional de propóleos. Bueonos-Aires, Argentina: p. 97.

Takaisi-Kikuni, N., \& Schilcher, H. (1994). Electron microscopic and microcalorimetric investigations of the possible mechanism of the antibacterial action of a defined propolis provenance. Planta Med., 60(3): 222-227. https://doi.org/10.1055/s-2006-959463

Tegos, G., Stermitz, F. R., Lomovskaya, O., \& Lewis, K. (2002). Multidrug pump inhibitors uncover remarkable activity of plant antimicrobials. Antimicrob. Agents Chemother., 46(10): 3133-3141. https://doi.org/10.1128/aac.46.10.3133$\underline{3141.2002}$

Vardar-Ünlü, G., Silici, S., \& Ünlü, M. (2008). Composition and in vitro antimicrobial activity of Populus buds and poplar-type propolis. World $J$. Microb. Biot., 24(7): 1011-1017.https://doi.org/10.1007/s11274-007-9566-5

Vieira, R. H., Rodrigues, D. P., Gonçalves, F. A., Menezes, F. G., Aragão, J. S., \& Sousa, O. V. (2001). Microbiocidal effect of medicinal plant extracts (Psidium guajava Linn. and Carica papaya Linn.) upon bacteria isolated from fish muscle and known to induce diarrhea inchildren. Rev. Inst. Med. Trop. Sao Paulo, 43(3): 145-8.https://doi.org/10.1590/S0036-46652001000300005

Vijay, D. W. (2013). Propolis: A wonder bees product and its pharmacological potentials. Adv. Pharmacol. Sci., Article ID 308249, 11 p.https://doi.org/10.1155/2013/308249

Zeghad, N. (2009). Etude du contenu polyphénolique de deux plantes médicinales d'intérêt économique (Thymus vulgaris, Rosmarinus officinalis) et évaluation de leur activité antibactérienne. Mémoire de Magister, Université de Constantine.

Zhang, J., Cao, X., Ping, S., Wang, K., Shi, J., Zhang, C., Zheng, H., \& Hu, F. (2015). Comparisons of ethanol extracts of chinese propolis

(poplar type) and poplar gums based on the antioxidant activities and molecular mechanism. Evid. Based Complementary Altern. Med., Article ID 307594, 15 p.http://dx.doi.org/10.1155/2015/307594 